\title{
Climate Change, Energy Developments and Perceptions of Place
}

\author{
Amanda D. Boyd' and Amanda Miller \\ The Edward R. Murrow College of Communication, Washington \\ State University, Pullman, WA, United States
}

\section{Abstract}

It is important to understand public perceptions of energy systems, particularly those located in rural areas where energy technology is likely to be situated. The general public can sometimes influence the deployment of energy systems through their opposition to, or support for, such development. This paper examines perceptions of energy systems and climate change in relation to public perspectives of "place" (i.e., relationships with the area and landscape). Sixty-nine residents from two communities were interviewed to examine their attitudes toward climate change and energy development. The results demonstrate that sense of place is an important factor in participants' preferences for energy systems. Participants were supportive of energy development if it was seen to be consistent with their perception of the area and landscape. Further, participants consistently referred to place when discussing the influence of climate change. The results of this study highlight the importance of understanding local residents' views on "place" when assessing their perception of climate change and their support for, or opposition to, transitioning to renewable energy systems.

Keywords: risk perception, place, climate change, energy systems, wind, hydro, oil, rural

\section{Introduction}

Risks associated with climate change and concerns about environmental sustainability have engendered the need to transition to low carbon energy systems. Public opinion is recognized as an important factor in the successful development or deployment of new energy systems (Devine-Wright, 2005). It is particularly important to understand the risk perceptions of rural populations, as energy systems are often located in rural areas and residents can influence deployment through their support for, or opposition to, a technology (Ashworth et al., 2010).

1 Corresponding author: amanda.boyd@wsu.edu. 
Understanding risk perceptions is critical for effective risk communication among scientists, policy-makers, the public, and other stakeholders (Miller, 2001; Sjoberg, 1998). Ascertaining risk perceptions about traditional or alternative energy systems can provide stakeholders and policy-makers with insight into how the public is likely to react toward a development (Covello \& Sandman, 2001), which, in turn, can facilitate the effective delivery of risk messages by communicators to the public (Leiserowitz, 2006). A thorough examination of risk perceptions is important because attitudes and behaviors can be influenced by multiple social and psychological factors that go beyond the scientific and technical risk assessment of a hazard (Pidgeon et al., 2003; Slovic, 1987).

A number of studies have examined the variables that influence perceptions of energy development (Walker et al., 2010; Wüstenhagen et al., 2007). However, less research has focused on local residents' attachment to "place" (i.e., relationships with the land and the desire to change or protect the landscape) and how this attachment may affect perceptions of energy systems (e.g., natural gas extraction, wind turbine siting, nuclear power plants, and solar photovoltaic development) and attitudes to climate change-knowledge that could provide stakeholders with information leading to better, more effective, discussions about climate change and energy development with local populations.

For this project, case studies were completed in two rural Canadian communities to assess perceptions of energy development and understandings of climate change. Extensive fossil fuel extraction currently occurs in the two communities, which are located in the provinces of Saskatchewan and Alberta. The case studies provide insight into participants' views regarding a shift in energy systems developmentfrom high carbon, fossil fuel-based energy systems to low carbon, renewable energy alternatives. Further, we examine how place-based elements influence attitudes toward climate change.

This paper begins with a description of energy systems development in Canada, followed by a review of factors that may influence attitudes toward energy development and climate change. We then provide information about the case study methodology and profiles of the two communities. Finally, we present our results and provide recommendations for future research.

\section{Background}

\section{Climate and energy context in Canada}

Many countries, including Canada, have acknowledged the need to diversify energy systems and increase the use of renewable resources to produce energy. The reasons for this diversification are numerous, including pressure for energy 
security, job creation, rural development, and the threat of decreasing fossil fuel reserves (International Energy Agency, 2011). Further, concern over pollution levels and increasing greenhouse gas (GHG) emissions have created the need to promote alternative, renewable energy technologies, such as solar photovoltaics and wind turbines (Intergovernmental Panel on Climate Change [IPCC], 2015), and find new locations for these.

Canada has relatively high levels of GHG emissions, including substantial carbon dioxide $\left(\mathrm{CO}_{2}\right)$ emissions. The country accounts for $0.5 \%$ of the world's population, yet is responsible for approximately $2 \%$ of the world's GHG emissions (Environment Canada, 2012). Ample research has shown that an increase in anthropogenic $\mathrm{CO}_{2}$ levels has contributed to climate change and that these levels need to be reduced (IPCC, 2015). Electricity generation is one of the contributing factors leading to high $\mathrm{CO}_{2}$ levels in the atmosphere.

In Canada, electricity is generated from a diversified mix of renewable and nonrenewable sources. These differ by region and depend on a number of factors, such as the availability of nearby natural resources (Natural Resources Canada, 2015). In Canada, the bulk of electricity is produced from hydropower in locations where favorable geography and hydrography exist (e.g., Quebec, British Columbia, Ontario, Labrador, and Manitoba) (Natural Resources Canada, 2015). Electricity in the Prairie Provinces (i.e., Alberta and Saskatchewan) is primarily generated by coal and natural gas-fired power plants. Extensive fossil fuel production in this region is due, in part, to the region's large fossil fuel basins.

The need to reduce $\mathrm{CO}_{2}$ emissions in high fossil fuel extraction regions (e.g., the provinces of Alberta and Saskatchewan) has prompted significant research regarding additional energy systems and raised important questions: Would communities continue to support only fossil fuel extraction or would they recommend other energy development in the area? Due to the fact these communities already support industrial development, would residents be more likely to support additional technologies? Communities with a history of fossil fuel extraction often depend on those industries for employment and economic development (Freudenburg \& Gramling, 1992); therefore, it is critical to examine how communities perceive additional energy systems development.

\section{The role of sense of place in perceptions of energy technology}

There are risks associated with energy systems technologies; however, there are also ample benefits (Wiener \& Graham, 2009). The need to examine rural communities' perceptions of energy systems technology to better communicate the risks and benefits of developments is well-established (Devine-Wright, 2011b). Public opinion on any controversial technology can factor into its successful development 
and this is especially true of energy systems (O'Hare et al., 1983). Public support for (or opposition to) energy systems has been a factor in the development of energy infrastructure throughout North America (Owens \& Driffill, 2008). According to social scientists, public opposition has been a factor in the decline of new nuclear power reactors since the 1970s and was also significant in the 1990s-era moratorium on offshore drilling along many coastal areas in the United States (US) (Smith, 2002).

It is particularly important to understand local perceptions of energy development. Such views are critical because "affected" populations have a greater ability to halt renewable energy development in their area through opposition and protest (Ashworth et al., 2010). A number of factors affect rural community members' views of energy technology (Wong-Parodi \& Ray, 2009; Wüstenhagen et al., 2007). Elements shaping perceptions of technological development include the potential to upset or uphold social systems, health and biophysical systems, and economic systems (Freudenburg \& Gramling, 1992). Social systems generally refer to the degree of connectivity among people and the quality and quantity of social relations possessed by a population (Harpham et al., 2002). Changes to social systems can occur as interest groups mobilize their resources in an attempt to promote or oppose a development. Residents may be concerned about how a development will affect their relationships with others in the community (Gross, 2007). Further, changes to the physical environment can affect perceptions of energy systems. The deployment of technology, development of transportation systems, storage of hazardous materials, and/or renovation of facilities can result in changes to the physical environment. Such alterations can have significant effects on nearby communities and influence how residents perceive energy developments (Devine-Wright, 2011b). The opening and closing of economic opportunities can also be outcomes of technological development and can affect perceptions of energy development (Boyd, 2015). Examples of potential economic opportunities include increased jobs, business revenue and tourism; negative economic outcomes include a decrease in real estate values, tourism or business revenue. An energy development may be opposed if it could potentially detract from future economic development (Flynn et al., 1992); however, it could be supported if it was likely to create employment.

There are numerous factors that help to form local perceptions of energy systems. Community members' attachment to place may be one of these factors and, consequently, may influence their views on energy systems and climate change (Devine-Wright \& Howes, 2010; Sherren et al., 2016). The term "sense of place" has been used in many different ways; however, it can generally be described as the affective link between individuals and places (Tuan, 1977; for an overview, see Bott et al., 2003). Sense of place is mediated by biophysical and cultural aspects (Bott et al., 2003). Studies examining sense of place show that biophysical attributes can predict place attachment to constructed meanings of place (Stedman, 2003; 
Willox et al., 2012). Sense of place also consists of numerous social and cultural dimensions, including the cultural and historic context within which meanings, social interactions and values are created (Tuan, 1977). In regard to energy development, sense of place can act as an obstacle or accelerator (Rollero \& De Piccoli, 2010). Research has found that, when an individual's pre-existing emotional bonds to a place are disrupted, energy development may be seen as a threat that can result in place-protective action, such as oppositional behavior (Devine-Wright \& Howes, 2010). For example, research on wind turbine development demonstrates that the technology must fit with the community's views of the area; if the development is perceived as "industrializing" a "natural" place, the incompatibility can lead to opposition and protest among community members (Devine-Wright \& Howes, 2010; Boyd, 2017).

Place attachment has also been shown to positively predict acceptance of energy projects; change does not always negatively affect or "disrupt" attachment to placeit has the ability to enhance attachment and predict support or acceptance as well (Devine-Wright, 2011a). While there has been research that suggests that place can influence perceptions of energy systems in regions that are viewed as "natural" (i.e., minimal energy development), less research has examined the perceptions of people living in regions with extensive energy development. Therefore, it is necessary to examine the views of those living with extensive energy development to better understand and predict how residents could view potential changes in their region.

\section{The role of sense of place in perceptions of climate change}

Sense of place reinforces and reflects the social construction of risk in the local environment; it can be seen as central to the process by which people select and interpret risks as salient, such as those associated with climate change (Masuda \& Garvin, 2006). Place-related social identity can be associated with attitudes toward, and concern about, local environmental issues and climate change (Hess et al., 2008). This association has been highlighted by researchers who have examined rural farmers' perspectives on climate change in Ethiopia (Deressa et al., 2009) and Sahel (Mertz et al., 2009). In these studies, rural populations related crises such as drought with personal experiences and observations.

The factors that influence beliefs and decisions about climate change are discussed in a growing body of literature that explores the role of information obtained through others (e.g., statistical descriptions) versus the role of information obtained through personal experience (Weber, 2006). The same information can lead to different choices depending on its source (Hertwig et al., 2004). This finding is particularly relevant for assessing rural communities' beliefs and decisions about climate change, as these populations often rely on personal experience and 
observations to assess risk (Mertz et al., 2009). Therefore, it is critical to understand local public values-including sense of place-and how these may influence perceptions of energy technology and climate change (Devine-Wright, 2005).

\section{Community profiles}

Two communities in two Canadian provinces were examined. The communities were chosen because each had large fossil fuel developments in addition to other proposed or possible renewable energy developments. Discussions with residents about potential and realized energy systems developments were used to evaluate how local, social contexts influenced perceptions about energy developments. The communities we examined were Fairview, Alberta, located near a proposed nuclear power plant and hydroelectric dam, with existing considerable natural gas development, and Weyburn, Saskatchewan, located on the Bakken oil field. The following section provides an overview of the energy systems currently located or proposed in these communities.

\section{Fairview, Alberta: Nuclear, hydro and natural gas development}

Fairview is located approximately 560 kilometers (350 miles) north of Edmonton. The nearest population centers are Grande Prairie, 114 kilometers (70 miles) to the south, and Peace River, 80 kilometers $(50$ miles) to the northeast. Surrounded by farmland, boreal forest and wetlands, the town of Fairview has a population of 3,297 and the Municipal District ${ }^{2}$ (MD) has 1,432 residents (Statistics Canada, 2012). The population of Fairview grew by 4.5\% between 2001 and 2006; however, the broader MD experienced a population decrease of $20.5 \%$ over the same period. The primary industries in the area include natural gas extraction and agriculture. Approximately $21 \%$ of residents in the town, and $40 \%$ of residents in the municipality, work in "agriculture and resource-based industries" (compared to $12 \%$ of the Albertan population). Other major employers in the area include a small branch campus of Grande Prairie Regional College and a tree nursery.

The town is situated on a large natural gas reserve (the Dunvegan Natural Gas Field) and near a river that is suitable for hydroelectric projects. Large natural gas fields south of Fairview provide employment opportunities for many in the area. The company, Canadian Natural Resources Ltd, employs approximately 115 people in the MD and 45 people in town. A hydroelectric project was proposed on the Peace River, 25 kilometers (15 miles) south of the town. It was estimated that construction

2 A "Municipal District" is a type of rural municipality in the Province of Alberta that is governed by elected councils. 
of the dam would take three to four years and would generate approximately 500 person-years of employment (Town of Fairview, 2012). The community was also involved in the North Peace nuclear power debate, which involved a proposal to build a power plant 45 kilometers ( 27 miles) northeast of Fairview. The proponent eventually withdrew the application and canceled the project. ${ }^{3}$

\section{Weyburn Saskatchewan: Oil development}

Weyburn is located 115 kilometers (70 miles) southeast of Regina and 75 kilometers (45 miles) north of the American border. The economic and business center for the region, Weyburn provides goods and services to nearby towns. Most of the area comprises flat farmland and there is little variation in topography. According to census data, the population of the Weyburn area is 10,622. Agriculture and oil make up the region's primary industries. In addition to the area's significant oil resources, the region has the country's largest privately owned inland grain terminal. Just over one-quarter of residents (26\%) in the Rural Municipality (RM) work in "occupations unique to primary industry" (e.g., the oil industry or farming), twice the provincial average (13\%); however, only $10 \%$ of those living within the city of Weyburn work in such occupations. Approximately $35 \%$ of residents in the RM of Weyburn work in "agriculture and other resource-based industries," compared to the provincial average of $16 \%$.

There is a long history of oil extraction in the Weyburn area due to the large oil reserves underlying southern Saskatchewan. More than 600 wells operate in the immediate area (City of Weyburn, 2011). There are two major oil field developers in the area: Cenovus and Apache. Cenovus operates the Weyburn field and employs about 80 people in the Weyburn area; the Apache oil company employs approximately 28 people (Apache, 2011). Other smaller oil companies also employ local residents.

\section{Methods}

Perspectives on climate change and energy systems were examined through individual and group interviews. In-depth, face-to-face individual and group interviews were completed with 33 people in Weyburn and 36 people in Fairview. Table 1 provides a summary of the number of individual interviews and number of participants in each group interview.

3 The proposal for the nuclear power plant was cancelled after this study was completed. 
Table 1. Summary of participants in research project by community

\begin{tabular}{|l|r|r|r|}
\hline & \multicolumn{1}{|c|}{ Fairview } & \multicolumn{1}{|c|}{ Weyburn } & \multicolumn{1}{|c|}{ Total participants } \\
\hline One-on-one interviews & 17 & 29 & 46 \\
\hline Group interviews with: & $2(4$ people) & 2 (4 people) & \\
2 people & $2(6$ people) & & \\
3 people & $1(4$ people) & & 6 \\
4 people & $1(5$ people) & & 4 \\
5 people & 36 & 33 & 59 \\
\hline Total number of participants & & & 6 \\
\hline
\end{tabular}

Note. Table 1 demonstrates the number of one-on-one interviews (individual interviews) and group interviews. The group interview column demonstrates the number of people in each group interview. For example, in Fairview there were 17 one-on-one interviews, 2 group interviews with 2 people present, 2 group interviews with 3 people present, 1 group interview with 4 people present, and 1 group interview with 5 people present.

Internet and phone listings were used to find initial interview participants; two participants were randomly selected from two local community websites and three residents were randomly selected from phone listings. An advertisement was placed in each of the local newspapers to recruit participants, and snowball sampling was also used. Snowball sampling is a method by which participants in the study recommend additional participants (Biernacki \& Waldorf, 1981). Efforts were made to ensure variety in terms of demographics (age, gender, education), location (rural or urban), and job type (agriculture, oil industry, government, business, other). Sufficient variation among respondents was ensured in four ways: 1) by maintaining a tally of respondents' demographics and job type throughout the interview process (e.g., if there were no respondents from the oil industry we would ask participants to identify other residents who worked in the oil industry); 2) by asking participants to recommend various residents (i.e., not just their close friends); 3) by recruiting from different sources to ensure that participants were members of different social networks (Heckathorn, 2002); and 4) by recruiting through local newspaper advertisements in both Fairview and Weyburn. The participants demographic characteristics are summarized in Table 2.

Table 2. Summary of participants' demographics, location and job type

\begin{tabular}{|c|c|c|}
\hline & Fairview & Weyburn \\
\hline \multicolumn{3}{|c|}{ Demographics } \\
\hline \multicolumn{3}{|l|}{ Age } \\
\hline $18-29$ & 4 & 4 \\
\hline 30-39 & 6 & 4 \\
\hline $40-49$ & 7 & 7 \\
\hline $50-59$ & 9 & 8 \\
\hline
\end{tabular}




\begin{tabular}{|c|c|c|}
\hline & Fairview & Weyburn \\
\hline \multicolumn{3}{|l|}{ Demographics } \\
\hline $60-69$ & 4 & 6 \\
\hline 70 and over & 4 & 3 \\
\hline Unknown* & 2 & 1 \\
\hline \multicolumn{3}{|l|}{ Gender } \\
\hline Male & 16 & 13 \\
\hline Female & 20 & 20 \\
\hline \multicolumn{3}{|l|}{ Education } \\
\hline No certificate, diploma, or degree & 3 & 6 \\
\hline High school certificate or equivalent & 10 & 7 \\
\hline College or other non-university certificate or diploma & 10 & 10 \\
\hline University certificate or diploma below bachelor level & 4 & 3 \\
\hline University certificate, diploma, or degree & 8 & 6 \\
\hline Unknown & 1 & 1 \\
\hline \multicolumn{3}{|l|}{ Location $^{\star \star}$} \\
\hline Rural & 17 & 13 \\
\hline Urban & 19 & 20 \\
\hline \multicolumn{3}{|l|}{ Job Type*** } \\
\hline Agriculture & 10 & 9 \\
\hline Fossil fuel industry & 5 & 4 \\
\hline Government & 3 & 3 \\
\hline Business (other than fossil fuel) & 9 & 7 \\
\hline Other & 9 & 10 \\
\hline
\end{tabular}

* "Unknown" indicates that the participant did not disclose the requested information. ** Location refers to where the participant lives (not where he or she works). ${ }^{\star \star *}$ Participants may have had more than one job type (e.g., owned a business and was mayor of the town). If they had more than one job, they were asked to speak about their main job.

A semi-structured approach was used to allow for additional questions exploring a particular problem or individual experience (Ansay et al., 2004) — namely, climate change and energy systems development. Similar interview protocols were used for both individual and group interviews. During the interviews, participants were asked to clarify or expand upon their responses. Interviews were completed during MayJuly 2011 in Fairview and September-November 2011 in Weyburn. A researcher stayed in the region during these months to observe community functioning and to better understand local contexts and sense of place. Community members were interviewed until a saturation point was found. A saturation point is achieved when emergent patterns in the data stabilize and no novel information is gained from additional respondents (Strauss \& Corbin, 1990). The questions focused on two areas: 1) what energy systems should be developed in the region and 2) perceptions of climate change. 
All interviews were transcribed and imported into a qualitative data analysis program (N-Vivo 9). Inductive and deductive approaches were utilized to facilitate the processes of thematic analysis. A deductive approach utilizes existing research questions and theories to guide the elaboration of themes (Corbin \& Strauss, 2008). Initial themes were gleaned from studies focusing on place (e.g., Devine-Wright, 2005) and a literature review of perceptions of energy technologies. A complimentary inductive approach resulted in the emergence of themes related to perceptions of climate change and energy systems (Corbin \& Strauss, 2008).

\section{Results}

\section{Attitudes toward energy systems development}

A total of 69 residents from the two communities were asked about their attitudes toward energy systems development. The participants' preferences for energy systems differed across the communities. Figure 1 shows the energy systems that residents would like to see developed. ${ }^{4}$ Fairview participants primarily discussed a desire for hydroelectricity development. There were fewer who wanted solar, wind and nuclear energy; yet, there were some participants who recommended the development of these energy sources. In Weyburn, wind turbine development was the most frequently mentioned energy source.

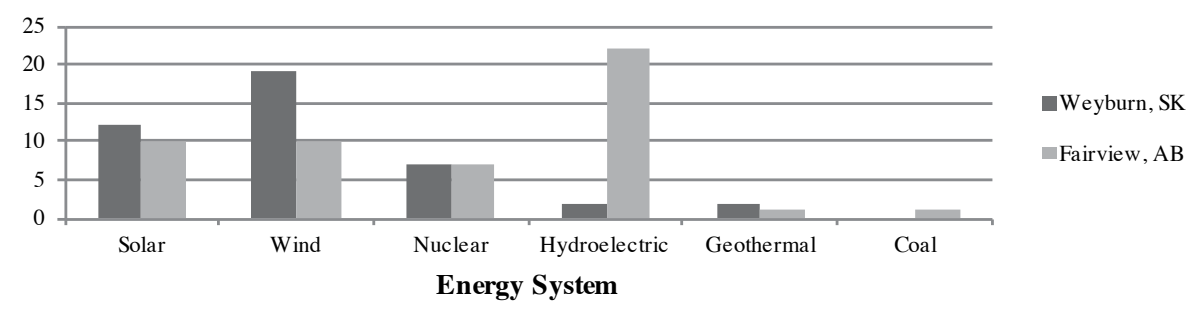

Figure 1. Preferences for local energy systems development

Overall, in both communities, large numbers of participants supported renewable resource development. It is noteworthy that no participants in either community were opposed to additional energy development in the area. The reasons why residents chose different energy systems are discussed in the following section.

4 Residents may have stated one or more preferences for energy systems - this has been captured in the graph. 


\section{An examination of place-based factors in energy preferences}

During the interviews, follow-up questions were asked to better understand participants' attitudes toward energy systems. Place-based factors were the most prominent variables. These were influenced by two factors: 1) the presence of resources in the region and 2) the importance of community and sustainability.

\section{Presence of resources in the region}

A common response among participants was that energy systems should be developed based on the resources present in the area. The majority of Fairview participants stated that there should be a focus on developing hydroelectric dams, primarily because of the proximity of the Peace River. One resident stated:

I think we really need to do more hydro. We have that big beautiful river running through our area. Why don't we use hydroelectricity here? I heard it might even bring more jobs ... we need more hydro.

Other participants from Fairview commented on what they thought would not work in the area; for example, "you can't really do solar up here because I don't think there's enough sun coming in." Another participant suggested that:

Wind might not work so well here and we aren't a real windy place here. I think the real big thing we need to do is to look to the river. We need to make hydroelectricity.

Similar types of responses were discovered in the Weyburn area. Owing to the area's location, Weyburn participants favored wind development. For example, a Weyburn resident commented: "Well, personally, I think that we should use more wind power because God knows we have enough of it here. It's extremely windy." A number of participants also mentioned that nuclear power could be a good option for the area, due to the uranium mines in Saskatchewan. A local business owner stated: "I think there should be more focus put on the exploration of uranium-we have that in Saskatchewan.” Another resident observed:

I think we need to look at the nuclear option, I went on a uranium tour and I think you need to look at your environment, I think you need to look at what we have to offer. Whether we need to expand what we already have or whether it's worth bringing something in that is totally different than what we had before.

\section{Importance of community and sustainability}

Beyond landscape, there are numerous reasons why "place" is important to people. Our research suggests that relationships with others living in the area could prove to be a significant factor in generating support for, or opposition to, energy systems. For example, an interviewee in Fairview discussed how hydroelectric energy would be a benefit for the community at large: 
I was quite excited about the dam they were going to do on the Peace River. I find it very discouraging that there has been one roadblock after the other for them, because I felt that that was going to be a big asset to northern Alberta and solve some other issues in regards to river flow and bring employment for people to this area.

This interviewee's support for hydroelectric energy was connected to their desire for the Fairview community to be self-sufficient and sustainable. Many participants stated that "community" was a major reason for living in the area and that industry growth, including energy technology development, would help with community sustainability. Several participants commented that energy developments, such as a hydroelectric dam or nuclear power plant, could be situated in the region, provided the community benefited directly with more jobs and resources. For example, a Fairview resident stated:

I would be OK with nuclear power, especially if it helped produce electricity here and in the Peace Country, but not if the energy is just shipped off to run the oil sands.

There needs to be some benefit to the community.

\section{Attitudes toward climate change}

Opinions varied among participants on whether the climate was changing and, if it was changing, why such changes were occurring. Figure 2 illustrates the number of people who 1) thought that climate change was occurring, 2) thought that climate change was not occurring, and 3) were unsure whether climate change was occurring. Participants who stated that climate change was occurring were asked for their views on the cause. Most Fairview participants identified both anthropogenic and naturally occurring factors. Similar results were found in Weyburn.

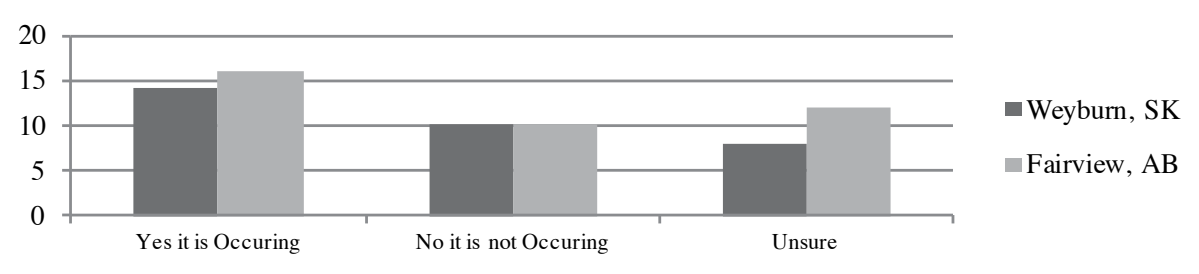

Figure 2. Belief that climate change is occurring

\section{Place-based observation and climate change}

A number of people referred to place-based observations when discussing their beliefs and attitudes toward climate change. Numerous interviewees in both communities stated that climate change was not occurring, backed up by observations of the land or weather around them. For example, a local business owner cited personal observations of the region to support his view that climate change was not occurring: 
Absolutely not! My feeling is absolutely not-there is no climate change. Last year we thought we were going to burn up because we didn't have rain. This year, every time you look up, it's raining ... climate change to me shouldn't be worried about, because just when you think it's getting warmer, it's going to be hot and we're going to be growing wheat in the Arctic, that is never going to happen. It was forty below last year. Where is this warming climate change, where is it?

Even those who stated that climate change was caused by anthropogenic factors recognized that it could be difficult to believe that climate change was occurring based on observations alone: "I mean, it's tough to look out the window and believe it, if you go elsewhere in the world maybe it would be more obvious." Many residents who believed that climate change was occurring also utilized placebased observations. A local farmer who believed that climate change was occurring discussed the changes he had witnessed over his lifetime:

There are major droughts for this area, the drought that we experienced during the last four years in this area is not normal and has never been normal. I've talked to guys that have been farming here since 1938 that have never seen four years consecutive drought as severe as what we had. So that's a climate change.

\section{Relationships between climate change, environmental concern and preferences for energy systems}

A prominent theme throughout the interviews was discussion of the need for environmental protection to reduce pollution. This was one of the reasons why many residents favored the development of less carbon intensive energy systems, such as nuclear, wind, solar and hydroelectric energy. Many participants in the Fairview area supported hydroelectric energy not only because of the close proximity of the Peace River, but also because they believed it would not produce as much pollution as other sources. Participants in Weyburn expressed similar sentiments; for example, a local municipal government worker observed that "we really need to start developing energy sources that don't pollute so much. Coal is good for the province, but really, we need to use things like wind and solar."

Regardless of what they believed about climate change, most participants stated that it was important to reduce carbon emissions and/or pollution from carbon intensive energy systems such as coal-fired power plants. A Fairview resident stated:

I don't really like saying this here, because I am likely to get shot. But really, we need to cut down on fossil fuels. Not really because of that climate thing, but because of environmental change.

A disconnect existed among many of the participants' statements regarding climate change and reducing $\mathrm{CO}_{2}$ emissions. A number of interviewees were adamant that climate change did not exist; yet, they agreed that carbon dioxide emissions 
should be reduced. A Weyburn resident who stated that there was no climate change also stated: "We need to reduce our carbon emissions; a lower carbon footprint can't hurt."

Many interviewees exhibited knowledge gaps about climate change (e.g., that carbon dioxide needed to be reduced due to the "ozone problem") and confused the concepts of "weather" and "climate" (e.g., "from minute to minute the climate can change- that doesn't mean that there are problems and that we should freak out"). The number of misconceptions about climate change, and the fact that they were not necessarily linked to local observations, is an area for further research, as discussed below.

\section{Discussion and conclusions}

This research has provided insights into rural communities' perceptions of energy systems and climate change. The results show that there are a number of key variables that influence perceptions of energy systems and climate change. Two of the most influential factors are 1) place-based observations and 2) the value of self-sufficient and sustainable communities. Understanding how these variables affect residents' opinions enables effective communication of the risks and benefits to affected communities.

This research has provided information regarding local risk perceptions and why rural communities may support or oppose energy systems. It is important to understand that people often value their natural resources, such as rivers. The results of this study support earlier research showing that new energy development does not always disrupt perceptions of place (Devine-Wright, 2011b). Rather, developments have the ability to enhance place attachment when views of place and energy systems are congruent. When a person feels attached to a place that they view as "natural," energy technologies that are also perceived as "natural" and not "industrial" will likely gain support from a community (Devine-Wright, 2011a). Therefore, understanding residents' views of "place" may benefit policy-makers, proponents and opponents to anticipate responses to projects.

Further, this study's findings signify that rural residents may be in favor of energy systems development "in-their-backyard." Proponents of the not-in-my-backyard (NIMBY) or locally unwanted land use (LULU) paradigm, suggest that local populations generally oppose technological risk in their locality (Dear, 1992), especially when such risks are imposed for the advancement of the broader society (Lukes, 2005). Yet, the responses of residents in Fairview and Weyburn suggest that locally affected populations may be in favor of technological development if 1) the development does not disrupt their perceptions of place and 2) there are benefits to the residents living in the location (e.g., increased employment opportunities and 
use of the electricity produced in the area). This research supports previous studies that conclude that procedures must be "fair" in the siting or location process (Besley, 2010). Fairness is often defined in terms of whether an individual perceives the result of a decision to be equitable (Lind \& Tyler, 1988); this research extends the concept of fairness to incorporate "place."

The results of this study have implications for those tasked with understanding perspectives about climate change and/or energy systems for rural communities. First, it is important to recognize that, while some people may not believe in a changing climate, they may agree that there is a changing environment. It is also important for people to understand that, while local observation and knowledge is important, observing day-to-day weather patterns may not be an indication that climate change is or is not occurring (Leiserowitz, 2005).

Perceptions of place can moderate climate change beliefs and policy positions. However, support for, or opposition to, certain energy systems may be contingent upon whether perceptions of place are threatened. Studies have found that the diffusion of energy technologies cannot solely be explained by resource availability and location (see, e.g., Stephens et al., 2009; Wilson et al., 2008). These studies call for increased understanding of the complex sociopolitical context associated with energy developments. The residents of the two communities studied here likely supported the technologies that were concomitant with resource availability because the developments did not threaten their perceptions of place. The developments they preferred not only aligned with the biophysical aspects of the regions, but also cultural aspects, which included the potential for these technologies to support local jobs thereby sustaining the community. The results of this study are consistent with research that affirms that people are more likely to oppose developments that are not compatible with their sense of place (van der Horst, 2007). Additional research could examine how perceptions of resource availability, place attachment and sociopolitical factors influence perceptions of energy technologies.

Future research could examine communication about energy systems and GHG emissions. Surprisingly, most residents did not link $\mathrm{CO}_{2}$ emissions to energy production. Similar findings have been noted in other studies (Löfstedt, 1991). This could be an illuminating and important area for future research, as communicators need to have a clear understanding of these perceptions to develop effective messages that appeal to target audiences. In addition, further research could involve follow-up studies in the two communities to examine whether perceptions of energy developments or climate change fluctuate over time. Raymond et al. (2017) recommend that researchers examine how sense of place changes during different stages of life. Future studies could explore whether perspectives of energy developments or climate change vary in these communities, and whether sense of place plays a role in how these perspectives change (or remain stable). 
The main limitation of this study was its size. Exploratory individual and group interviews were used to discover perspectives on climate change and energy systems, facilitating a broad understanding of local residents' risk perceptions; however, a larger survey of different communities and different energy systems may provide a different, enlarged view. Asking further questions about energy systems could also expand this research, particularly energy systems that the public are opposed to. This information could further provide insights into risk perceptions and place-related variables.

This research demonstrates that residents of rural communities may be more likely to favor energy systems that utilize local natural resources that are readily available and are consistent with local residents' perceptions of "place." When dealing with an energy system or resource that is not tied with the local area, it is important to understand the perceived risks and benefits of those systems. These key findings will enable more effective communication with affected audiences about energy systems and climate change.

\section{References}

Ansay, S. J., Perkins, D. F., \& Colonel, J. N. (2004). Interpreting outcomes: Using focus groups in evaluation research. Family Relations, 53, 310-316. doi.org/10.1111/j.00222445.2004.0007.x

Apache. (2011). Display at Weyburn EOR Exhibit. Weyburn, Canada.

Ashworth, P., Boughen, N., Mayhew, M., \& Millar, F. (2010). From research to action: Now we have to move on CCS communication. International Journal of Greenhouse Gas Control, 4, 426-433. doi.org/10.1016/j.ijggc.2009.10.012

Besley, J. C. (2010). Public engagement and the impact of fairness perceptions on decision favorability and acceptance. Science Communication, 32, 256-280. doi.org/10.1177/ 1075547009358624

Biernacki, P., \& Waldorf, D. (1981). Snowball sampling: Problems and techniques of chain referral sampling. Sociological Methods and Research, 10, 141-163. doi.org/10.1177/ 004912418101000205

Bott, S., Cantrill, J. G., \& Myers Jr, O. E. (2003). Place and the promise of conservation psychology. Human Ecology Review, 10(2), 100-112.

Boyd, A. D. (2015). Connections between community and emerging technology: Support for enhanced oil recovery in the Weyburn, Saskatchewan area. International Journal of Greenhouse Gas Control, 32, 81-89. doi.org/10.1016/j.ijggc.2014.11.005 
Boyd, A. D. (2017). Examining community perceptions of energy systems development: The role of communication and sense of place. Environmental Communication, 11(2), 184-204. doi.org/10.1080/17524032.2015.1047886

City of Weyburn. (2011). Weyburn Profile. Retrieved from: www.weyburn.ca/weyburnprofile

Corbin, J., \& Strauss, A. (2008). Basics of qualitative research: Techniques and procedures for developing grounded theory. Thousand Oaks, CA: SAGE Publications. doi.org/10.4135/ 9781452230153

Covello, V., \& Sandman, P. M. (2001). Risk communication: Evolution and revolution. In A. Wolbarst (Ed.), Solutions to an environment in peril. Baltimore, MD: John Hopkins University Press.

Dear, M. (1992). Understanding and overcoming the NIMBY Syndrome. Journal of the American Planning Association, 58, 288-300. doi.org/10.1080/01944369208975808

Deressa, T. T., Hassan, R. M., Ringler, C., Alemu, T., \& Yesuf, M. (2009). Determinants of farmers' choice of adaptation methods to climate change in the Nile Basin of Ethiopia. Global Environmental Change, 19(2), 248-255. doi.org/10.1016/j.gloenvcha. 2009.01.002

Devine-Wright, P. (2005). Beyond NIMBYism: Towards an integrated framework for understanding public perceptions of wind energy. Wind Energy, 8, 125-139. doi.org/ $10.1002 /$ we. 124

Devine-Wright, P. (2011a). Place attachment and public acceptance of renewable energy: A tidal energy case study. Journal of Environmental Psychology, 31, 336-343. doi.org/ 10.1016/j.jenvp.2011.07.001

Devine-Wright, P. (2011b). Renewable energy and the public: From NIMBY to participation. London, England: Earthscan.

Devine-Wright, P., \& Howes, Y. (2010). Disruption to place attachment and the protection of restorative environments: A wind energy case study. Journal of Environmental Psychology, 30, 271-280. doi.org/10.1016/j.jenvp.2010.01.008

Environment Canada. (2012). Greenhouse Gas Emissions Data. Retrieved from: www.canada.ca/en/environment-climate-change/services/environmental-indicators/ greenhouse-gas-emissions.html

Flynn, J., Burns, W., Mertz, C. K., \& Slovic, P. (1992). Trust as a determinant of opposition to a high-level radioactive waste repository: Analysis of a structural model. Risk Analysis, 12, 417-429. doi.org/10.1111/j.1539-6924.1992.tb00694.x

Freudenburg, W. R., \& Gramling, R. (1992). Community impacts of technological change: Toward a longitudinal perspective. Social Forces, 70, 937-955. doi.org/10.1093/sf/ 70.4 .937 
Gross, C. (2007). Community perspectives of wind energy in Australia: The application of a justice and community fairness framework to increase social acceptance. Energy Policy, 35, 2727-2736. doi.org/10.1016/j.enpol.2006.12.013

Harpham, T., Grant, E., \& Thomas, E. (2002). Measuring social capital within health surveys: Key issues. Health Policy and Planning, 17, 106-111. doi.org/10.1093/heapol/17.1.106

Heckathorn, D. D. (2002). Respondent-driven sampling II: Deriving valid population estimates from chain-referral samples of hidden populations. Social Problems, 49(1), 11-34. doi.org/10.1525/sp.2002.49.1.11

Hertwig, R., Barron, G., Weber, E. U., \& Erev, I. (2004). Decisions from experience and the effect of rare events in risky choice. Psychological Science, 15(8), 534-539. doi.org/ 10.1111/j.0956-7976.2004.00715.x

Hess, J. J., Malilay, J. N., \& Parkinson, A. J. (2008). Climate change: The importance of place. American Journal of Preventive Medicine, 35(5), 468-478. doi.org/10.1016/j. amepre.2008.08.024

International Energy Agency. (2011). Renewable Energy: Policy Considerations for Deploying Renewables (p. 76). Retrieved from: www.iea.org/publications/ freepublications/publication/Renew_Policies.pdf

IPCC (Intergovernmental Panel on Climate Change). (2015). Fifth Assessment Report. Retrieved from: www.ipcc.ch/report/ar5/

Leiserowitz, A. (2005). American risk perceptions: Is climate change dangerous? Risk Analysis, 25, 1433-1442. doi.org/10.1111/j.1540-6261.2005.00690.x

Leiserowitz, A. (2006). Climate change risk perception and policy preferences: The role of affect, imagery, and values. Climate Change, 77, 45-72. doi.org/10.1007/s10584-0069059-9

Lind, E. A., \& Tyler, R. T. (1988). The social psychology of procedural justice: New York, NY: Plenum Press.

Löfstedt, R. E. (1991). Climate change perceptions and energy-use decisions in Northern Sweden. Global Environmental Change, 1, 321-324. doi.org/10.1016/0959-3780 (91)90058-2

Lukes, S. (2005). Power: A radical view (2nd ed.). New York, NY: Palgrave Macmillian. doi.org/10.1007/978-0-230-80257-5

Masuda, J. R., \& Garvin, T. (2006). Place, culture, and the social amplification of risk. Risk Analysis, 26(2), 437-454. doi.org/10.1111/j.1539-6924.2006.00749.x

Mertz, O., Mbow, C., Reenberg, A., \& Diouf, A. (2009). Farmers' perceptions of climate change and agricultural adaptation strategies in rural Sahel. Environmental Management, 43(5), 804-816. doi.org/10.1007/s00267-008-9197-0 
Miller, S. (2001). Public understanding of science at the crossroads. Public Understanding of Science, 10, 115-120. doi.org/10.1088/0963-6625/10/1/308

Natural Resources Canada. (2015). Electricity Infrastructure. Retrieved from: www.nrcan. gc.ca/energy/electricity-infrastructure

O’Hare, M. H., Bacow, L., \& Sanderson, D. (1983). Facility siting and public opposition. New York, NY: Van Nostrand Reinhold.

Owens, S., \& Driffill, L. (2008). How to change attitudes and behaviours in the context of energy. Energy Policy, 36, 4412-4418. doi.org/10.1016/j.enpol.2008.09.031

Pidgeon, N. F., Kasperson, R. E., \& Slovic, P. (2003). The social amplification of risk. Cambridge, England: Cambridge University Press. doi.org/10.1017/CBO97805 11550461

Raymond, C.M., Kyttä, M., \& Stedman, R. (2017). Sense of place, fast and slow: The potential contributions of affordance theory to sense of place. Frontiers in Psychology, 8, 1674. doi.org/10.3389/fpsyg.2017.01674

Rollero, C., \& De Piccoli, N. (2010). Place attachment, identification and environment perception: An empirical study. Journal of Environmental Psychology, 30, 198-205. doi.org/10.1016/j.jenvp.2009.12.003

Sherren, K., Beckley, T. M., Parkins, J. R., Stedman, R. C., Keilty, K., \& Morin, I. (2016). Learning (or living) to love the landscapes of hydroelectricity in Canada: Eliciting local perspectives on the Mactaquac Dam via headpond boat tours. Energy Research \& Social Science, 14, 102-110. doi.org/10.1016/j.erss.2016.02.003

Sjoberg, L. (1998). Risk perception: Experts and the public. European Psychologist, 3, 1-12. doi.org/10.1027/1016-9040.3.1.1

Slovic, P. (1987). Perception of risk. Science, 236, 280-285. doi.org/10.1126/science.3563507

Smith, E. (2002). Energy, the environment, and public opinion. Lanham, MD: Rowman \& Littlefield Publishers.

Statistics Canada. (2012). 2011 Census Profile. Retrieved from: www12.statcan.gc.ca/ census-recensement $/ 2006 / \mathrm{dp}-\mathrm{pd} /$ prof/92-591/details/page.cfm?Lang=E\&Geo $1=$ CSD $\&$ Code $1=4819068 \&$ Geo $2=$ PR $\&$ Code $2=48 \&$ Data $=$ Count $\&$ SearchText $=$ Fairview $\&$ SearchType $=$ Begins $\&$ SearchPR $=01 \& B 1=$ All $\&$ Custom $=$

Stedman, R. C. (2003). Is it really just a social construction?: The contribution of the physical environment to sense of place. Society \&Natural Resources, 16(8), 671-685. doi.org/10.1080/08941920309189

Stephens, J. C., Rand, G. M., \& Melnick, L. L. (2009). Wind energy in US media: A comparative state-level analysis of a critical climate change mitigation technology. Environmental Communication, 3, 168-190. doi.org/10.1080/17524030902916640 
Strauss, A., \& Corbin, J. (1990). Basics of qualitative research-grounded theory procedures and techniques. Newbury Park, CA: SAGE Publications.

Town of Fairview. (2012). Business. Retrieved from: www.heartofthepeace.com/why-fairviewarea

Tuan, Y. F. (1977). Space and place: The perspective of experience. Minneapolis, MN: University of Minnesota Press.

van der Horst, D. (2007). NIMBY or not? Exploring the relevance of location and the politics of voiced opinions in renewable energy siting controversies. Energy Policy, 35(5), 2705-2714. doi.org/10.1016/j.enpol.2006.12.012

Walker, G., Devine-Wright, P., Hunter, S., High, H., \& Evans, B. (2010). Trust and community: Exploring the meanings, contexts and dynamics of community renewable energy. Energy Policy, 38, 2655-2663. doi.org/10.1016/j.enpol.2009.05.055

Weber, E. U. (2006). Experience-based and description-based perceptions of long-term risk: Why global warming does not scare us (yet). Climatic Change, 77(1), 103-120. doi.org/ 10.1007/s10584-006-9060-3

Wiener, J. B., \& Graham, J. D. (2009). Risk vs. risk: Tradeoffs in protecting health and the environment. Cambridge, MA: Harvard University Press.

Willox, A. C., Harper, S. L., Ford, J. D., Landman, K., Houle, K., \& Edge, V. L. (2012). "From this place and of this place": Climate change, sense of place, and health in Nunatsiavut, Canada. Social Science \& Medicine, 75(3), 538-547. doi.org/10.1016/ j.socscimed.2012.03.043

Wilson, E. J., Plummer, J., Fischlein, M., \& Smith, T. M. (2008). Implementing energy efficiency: Challenges and opportunities for rural electric co-operatives and small municipal utilities. Energy Policy, 36(9), 3383-3397. doi.org/10.1016/j.enpol. 2008.05.007

Wong-Parodi, G., \& Ray, I. (2009). Community perceptions of carbon sequestration: Insights from California. Environmental Research Letters, 4, 8. doi.org/10.1088/17489326/4/3/034002

Wüstenhagen, R., Wolsink, M., \& Bürer, M. J. (2007). Social acceptance of renewable energy innovation: An introduction to the concept. Energy Policy, 35, 2683-2691. doi.org/10.1016/j.enpol.2006.12.001 
This text is taken from Human Ecology Review, Volume 24, Number 1, 2018, published 2018 by ANU Press, The Australian National University, Canberra, Australia.

doi.org/10.22459/HER.24.01.2018.01 